\title{
JÓ PÉLDA-E KÍNA? FELTÁRÓ KUTATÁS A MOBIL KÖZÖSSÉGI KERESKEDELEMRÖL
}

A globalizálódó gazdaságban, az internet segítségével az üzleti tevékenységek új dimenziói nyílnak meg nap, mint nap. A digitális gazdaság keretei között az elektronikus kereskedelem (a továbbiakban: e-kereskedelem) fejlődése töretlen, melyhez a közelmúltban társultak a mobilkereskedelem (m-kereskedelem) által lehetővé tett kiegészítő megoldások. Az m-kereskedelem új lehetőségei révén a felhasználók bármikor és bárhol képesek üzleti tranzakciót folytatni, mint amilyenek például a helyalapú szolgáltatások. Ebben a technológiaalapú, nagyban innovatív környezetben kell a különféle piaci szereplőknek megfelelniük, a fogyasztók pedig egyre inkább szembesülnek azzal, hogy életük jelentős része az offline és az online tér között oszlik meg, különféle közösségimédia-felületeken, ahol a felhasználók folyamatos interakcióban vannak egymással és a velük kapcsolatban lévő értékesítő szervezetekkel. A szerzők online kérdőíves felmérés keretében vizsgálják meg a különféle m-kereskedelmi megoldások relevanciáját Magyarországon, a fogyasztók m-kereskedelmi alkalmazások használatára vonatkozó hajlandóságán és annak befolyásoló tényezőin keresztül. Az összehasonlítás alapjául Kína szolgál, ahol az alapfeltételek különböznek a magyar piactól, de mivel globálisan itt található a legfejlettebb m-kereskedelem technológiai és használati szempontból is, ezért koncentrálnak erre a piacra. Ebben a kontextusban elemzik a mobil közösségimédia-megoldásokon kialakuló szájreklám hatásait a fogyasztók vásárlási hajlandóságára és vásárlás utáni tevékenységeire. Eredményeik szerint a magyar felhasználók esetében a közösségi m-kereskedelmi applikációk bevezetése előtt nagyon fontos a fogyasztók oktatása és képzése, hogy már ismeretek birtokában legyenek képesek az újfajta megoldások befogadására.

\section{Kulcsszavak: internet, mobil média, közösségi média, e-kereskedelem, m-kereskedelem}

A globális információ- és kommunikációtechnológiák fejlődése során született modern vívmányok, valamint az internet a gazdasági tevékenység köré épülő globális elektronikus környezet létrejöttéhez vezetett. Ennek hatására új lehetőségek nyíltak meg az üzleti tevékenységek szervezeti és intézményi háttere, valamint a társadalmi és gazdasági tevékenységek egyéb területei számára. A termelés fö befolyásoló tényezőjévé az információ- és kommunikációtechnológia (IKT) vált, amely Hasnaoui és Freeman (2010, p. 386.) meghatározása szerint olyan technológiákat jelent, amelyek a telekommunikáción keresztül (pl. internet, vezeték nélküli hálózatok, mobiltelefonok) biztosítanak információkhoz történő hozzáférést, másrészt pedig az információkat továbbító csatornákat és a csatornákon futó információk hálózatba szerveződését is magukba foglalják. A digitális gazdaság egyik általános folyamata, hogy a különféle társadalmi és gazdasági tevékenységeket átalakítja és hozzáidomítja az IKT használata révén az internet elektronikus környezeti tényezőihez, mint amilyen az e-kereskedelem (Füzes et al., 2018). Azt a gazdaságot, amely elektronikus árukon és szolgáltatásokon alapulva végzi müködését, elektronikus üzleti tevékenységeket és elektronikus kereskedelmet folytat, valamint elektronikus fizetőeszközt használ, elektronikus vagy digitális gazdaságnak hívjuk. Ehhez a meghatározáshoz olyan fogalmak társulhatnak, mint az e-gazdaság, e-kormányzat, e-média, valamint e-learning (Berdykulova et al., 2014).

Az e-kereskedelem egy weboldalt használ üzletkötésre vagy termékek és szolgáltatások online értékesítésének megkönnyítésére. Az online kiskereskedelmi értékesítés az elmúlt években nagymértékü növekedést mutatott. Az online kiskereskedők előreláthatóan megfelelő, informatív és személyre szabott élményt fognak nyújtani mérhetetlenül különbözö típusú végfogyasztóknak és üzleti vállalkozásoknak is. A kiskereskedelmi polcárak, alkalmazottak és készletezési költségek megspórolásával az online kiskereskedők képesek lehetnek nyereségesen értékesíteni alacsony mennyiségben gyártott termékeket réspiacokon is. Az online kiskereskedők az üzletkötés három kulcs tényezője mentén versenyeznek egymással: a weboldalon történő vevői interakciók, a kiszállítás és a felmerülés idején kezelt problémákra való képesség mentén. Habár a végfogyasztói (business-to-consumer: B2C) weboldalak sok figyelmet vonzanak magukra a médián keresztül, még ezeknél is több üzleti tevékenység történik szervezetközi (business-to-business: B2B) oldalakon, ami a beszállítóvevő kapcsolatot mélyrétegeiben változtatja meg (Kotler - Keller, 2012). Az IKT és az e-kereskedelem a szolgáltató szektort, így például a turizmust is utolérte. Ma már az utazási irodák honlapjain is megjelennek olyan opciók, amelyek segítségével az utazó saját maga állíthatja össze az utazási csomagot saját számítógépén vagy mobileszközén. Ehhez pedig nem szükséges személyesen jelen lennie az irodában, mégis az utazási iroda kínálatát böngészi (Tóth-Kaszás, 2017, p. 237.).

A mobilkereskedelem (m-kereskedelem) meghatározás szerint áruk és szolgáltatások vétele és eladása mobileszközök segítségével, vezeték nélküli hálózatokon (Eastin et al., 2016). Az m-kereskedelem rendelkezik néhány elönynyel az elődjeihez képest, mivel a felhasználók tranzakciót folytathatnak az interneten keresztül bármikor, bárhonnan. Ezen felül, az m-kereskedelem merően új lehetőségeket kínál, mint amilyenek a helyalapú szolgáltatások. Az 
m-kereskedelem két fontos tényezője a felhasználók helyalapú és kontextusalapú azonosítása. Emellett azonban Ghose et al. (2016) is rámutatott, hogy a teljes vásárlási folyamat átlátása, azaz az online vásárlás offline előzményeinek begyüjtése és marketingkommunikációs, valamint értékesítésfókuszú felhasználása tovább javíthatja az m-kereskedelem hatékonyságát. Ennek révén pedig érdemes tudni, hogy nem feltétlenül elég az internetes fogyasztói magatartás, valamint a mobileszközzel követhető fizikai lokáció regisztrálása, hanem érdemes további, a klasszikus fogyasztói befolyásoló tényezők vizsgálata is (Ghose et al., 2016). Balasubramanian et al. (2002, p. 355.) gyüjtése alapján megállapítható, hogy az m-kereskedelmi applikációk alapvető jellemzőik és funkcióik alapján ugyan nem változtak, de a technológia fejlődése és a mobileszközok használatának elterjedése révén alkalmazásuk szélesebb körben vált elérhetővé. Az m-kereskedelem használatához hozzátartozik, hogy a különféle kereskedelmi platformokat a felhasználók gyakran applikációkon keresztül érik el, amelyek lehetővé teszik a kifinomult e-kereskedelmi szolgáltatások specializált elérését és használatát (Narang - Shankar, 2016). Narang és Shankar (2016) is felveti a kérdést, hogy az applikációkon keresztül történő vásárlások értéke hogyan viszonyul a későbbi tevékenységekhez (pl. újravásárlási hajlandóság), hiszen ez árnyalja az egyszerűen a vásárlás mennyiségére koncentráló vizsgálatokat, hiszen összességében - az m-kereskedelem vizsgálatában - a végső eredménytényező a vásárlások és újravásárlások mértéke, és ebből következően, a vállalati teljesítménytényezők vizsgálata segíthet az m-kereskedelem gyakorlati alkalmazásának kérdéséhez.

A fogyasztók mobiltelefonos kereskedelmi alkalmazások használatára vonatkozó hajlandósága egyre jelentősebb kérdéskör. Liebana-Cabanillas et al. (2017) a használati hajlandóság hat lehetséges befolyásoló tényezőjét vizsgálták meg, nevezetesen az észlelt hasznosságot, a használat észlelt könnyüségét, a bizalmat, a mobilitást, a személyre szabhatóságot és a használói bevonódást. Kutatásuk következtetése alapján kiemelik a személyre szabhatóság, használói bevonódás és bizalom fontosságát a mobiltelefonos kereskedelmi alkalmazások használati hajlandóságának a kialakításában. A bizalom szempontja kiemelten fontos, különösen akkor, amikor új szolgáltatások használatáról van szó, vagy olyan szolgáltatásokról, amelyeknek a pénzügyi értéke magas (Liebana-Cabanillas et al., 2017). Ez a modell hasonlóságot mutat Keszey és Zsukk (2017) kutatásával is, ahol a technológiahasználati szándék befolyásoló tényezőit vizsgálták különféle elméleti megközelítések szerint. Ashraf et al. (2016) az m-kereskedelem használati szándéka és tényleges használata - azaz a magatartási tényező - és ennek mozgatórugói (pl. egyediség és megszokás) közötti különbségeket elemezték, ahol az m-kereskedelmi készenlét ( $\mathrm{m}$-commerce readiness) fogalma moderáló tényezőként hatott a folyamatra, és ebből a szempontból érdekes eredményt jelentett, hogy az adott m-kereskedelmi megoldás egyedisége erőteljesen befolyásoló erejü a használati szándék és a tényleges használat tekintetében is. Az m-kereskedelmi készenlét fogalma ebből a szempontból azt az állapotot jelzi, hogy az adott fogyasztó milyen szakaszában van az adott technológia használatának.
Mobilkommunikációs eszköznek a hagyományos mobiltelefonok mellett ma már inkább az okostelefonokat és kisebb részben a táblagépeket érthetjük, amelyek az adaptív operációs rendszer lévén különböző applikációkat is futtathatnak. A mobileszközök ráadásul jellemzően személyesek, a felhasználók gyakorlatilag állandóan jelen vannak, ami a használati szokások és a helymeghatározás kombinációja nyomán további lehetőségeket is biztosíthat, ha ezek felhasználásához a használó hozzájárul (Horváth et al., 2013). Így nem véletlen, hogy az m-kereskedelem számára is e mobileszközök - különösen az okostelefonok - elterjedése nyitotta meg az utat, ahol a kereskedelemmel kapcsolatos applikációk is megjelenhettek, de a személyes jelleg miatt az okostelefonok egyben a közösségi média számára is fontos eszköznek bizonyultak.

A közösségi médiát meghatározhatjuk úgy, mint azokat az újmédia-technológiákat, amelyek egyszerüsítik az interaktivitást és a közös értékalkotást (co-creation), lehetővé teszik a felhasználók által létrehozott tartalmak fejlődését és megosztását szervezetek, valamint szervezetek és egyének között (Filo et al., 2015). A közösségi média internetalapú alkalmazásokat és alapvető fogalmakat takar, amelyek bár nem kizárólag, de - a web 2.0-án alapulnak, és lehetővé teszik a felhasználók közötti online interakciót annak érdekében, hogy a felhasználók kommunikáljanak egymással tartalmak, vélemények, szemléletek, meglátások, médiatartalmak és kapcsolatok létrehozása, átformálása és megosztása céljából. A közösségi média sok fajta kétirányú kommunikációs felület gyüjteménye, amely lehetővé teszi az ötletek, információ és értékek szabad áramlását az interneten keresztül (Csordás et al., 2014).

Mindazonáltal, a közösségi média fontossága abból adódik, hogy az emberek egyre inkább úgy viszonyulnak a közösségimédia-alkalmazásokhoz, mint mindennapi életüknek egy fontos szeletéhez, és egyre inkább valószínü, hogy interakcióik egy részét áthelyezik a virtuális felületekre. A közösségimédia-alkalmazásokra úgy tekinthetünk, mint az egyik leghatásosabb és leginkább nagy befolyású eszközökre, amelyek jelentős mértékben hatnak az emberek életének legtöbb területére, beleértve az élet társadalmi, kereskedelmi és üzleti oldalait. Gazdasági szempontból a közösségi média stratégiai szinten képes javítani a kétoldalú kommunikációt cégek és végfogyasztók között, és ehhez kapcsolódóan, képes a vevőket összekapcsolni a szervezetek márkáival. A közösségi média egyre növekvő mértékben úgy tekinthető a modern üzleti szereplők számára, mint ígéretes felület marketingkommunikációs tevékenységek végzésére, a célcsoportokkal folytatott hatékony kommunikációra (Alalwan, 2017). Így a közösségi média fontos hely, ahol az egyéni felhasználók megoszthatják nézeteiket egymással, de ezen kívül fontos, reklámozási nyereséget lehetővé tevő kommunikációs csatorna a vállalatok számára is.

A közösségi kereskedelem a közösségi média kereskedelmi tranzakciókra és tevékenységekre történő használatát jelenti, amelyeket első sorban a közösségi interakciók és felhasználói hozzájárulások ösztönöznek (Yan et al., 2016). Emellett a közösségi kereskedelem néhány esetben úgy is tekinthető, mint az e-kereskedelem egyik alkategóriája. A közösségimédia-felületeken túl a közösségi kereskedelem 
színes eszközkészlettel rendelkezik, mint amilyenek a felhasználói értékelések és a megtekintések, ajánlások és fórumok. A mobil közösségi kereskedelem úgy határozható meg, mint egy sor e-kereskedelmi tevékenység, amelyet mobil környezetben végeznek, és amelynek minőségét a felhasználók által létrehozott tartalom javítja (Hew et al., 2017). Kourouthanassis és Giaglis (2014) néhány évvel ezelőtt, amikor összegyüjtötték az m-kereskedelem akadémiai kutatásainak irányvonalait, már kiemelték a mobileszközökön folyó kereskedelmi tranzakciókba ágyazott közösségimédia-elemek és a kapcsolódó fogyasztóimagatartás-elemek fontosságát. Chang et al. (2015) már speciális környezetben elemezték az m-kereskedelmi vásárlási hajlandóság és a tényleges használat befolyásoló tényezőit, figyelembe véve az észlelt hasznosság és a használat észlelt könnyüségét. Chang et al. (2015) alapvetően Davis et al. (1989) technológia-elfogadási modelljéből (TAM: technology acceptance model) kiindulva elemezték az m-kereskedelem használatát, mely megközelítés segített a kutatási problémánk jobb megértésében.

Tehát a közösségi kereskedelem vásárlási és közösségi hálózati tevékenységek egyvelege, amely támogatja a közösségi interakciós tevékenységeket termékek és szolgáltatások vétele és eladása esetén, online közegben. Wang és Yu (2017) kutatták a közösségi hatás erejét a vásárlási hajlandóságra a közösségi kereskedelemben. A vásárlási hajlandóság kialakulása definíció szerint az a folyamat, amelyen keresztül egy fogyasztó kiválasztja, rendszerezi, szemlélteti és összehasonlítja a különféle vásárlási platformokról és csatornákról begyüjtött információkat, majd a folyamat végén kialakítja a döntéshez szükséges belső érvrendszerét (Sheth et al., 2004). Wang és Yu (2017) szerint a pozitív szájreklám (WOM: word-of-mouth) és a szájreklám tartalma erős pozitív hatással van a fogyasztók vásárlási hajlandóságára. Ezzel szemben a negatív szájreklám erős negatív hatással van a vásárlási hajlandóságra. Azt is kimutatták, hogy a jelentősebb mértékü vevői vásárlási hajlandóság magasabb tényleges vásárláshoz vezetett, és a hajlandóság a vásárlás utáni tevékenységek valódi befolyásoló tényezője (Wang Yu, 2017). Így a közösségi hatás ereje és a közösségi média tulajdonságai valóban befolyással bírnak a közösségi kereskedelem e-kereskedelmi jellemzőire, mivel a közösségi hatás befolyásolja a vásárlási hajlandóságot.

A következőkben arról fogunk beszélni, hogy a fent leírt trendek hogyan valósulnak meg Kínában, ahol nemzetközi összehasonlításban is olyan mértékű az internetes technológiák, ezen belül pedig az e-kereskedelem és az mkereskedelem térnyerése - valamint az m-kereskedelmi és közösségimédia-megoldások kombinált elterjedése -, hogy érdemesnek tartjuk a rövid kitekintést erre a gazdaságra a vizsgált kutatási probléma tekintetében. Természetesen a kínai mobileszköz-használat egyedi jellegzetességei miatt (sok esetben kimaradt a nem mobil eszközökön keresztül történő internethasználat, és az m-kereskedelem nem választás, hanem kényszer eredménye) következtetéseinket is csak korlátozások mellett, a kínai és a magyar piac összehasonlításának korlátai mentén hozzuk meg. Bronnenberg és Ellickson (2015) érdekes kontextusban elemzik a kiskereskedelem globális fejlődését, és kitérnek arra is, hogy külön- féle modern kiskereskedelmi formák (pl. e-kereskedelem) is terjedni kezdtek a fejlődő piacokon is. Kínában például az ekereskedelem térhódítása olyan méreteket öltött, hogy öt év alatt lehagyta az Egyesült Államokat. A modern kiskereskedelmi rendszerek jelentik jelenleg Kína kiskereskedelmi nyereségének $65 \%$-át, az online kiskereskedelmi formák pedig 31\%-át, ami 3210 millió dollár értéket jelentett 2014-ben (Bronnenberg - Ellickson, 2015, p. 132.). Ez a jelentős növekedés magyarázható a Kínában jellemző növekvő jóléttel és erőteljes urbanizációs folyamatokkal, illetve a kiskereskedelemben jellemző globális folyamatok jelentkezésével. A nagyobb alapterületü kiskereskedelmi egységek globális megjelenése, az ellátásilánc-integráció, valamint a specializált kiskereskedelmi egységek előretörése mind-mind elösegítői az e-kereskedelem Kínában (is, de globálisan itt a legnagyobb mértékben) tapasztalt jelentős fejlődésének.

\section{Az internet helyzete Kínában}

A kulturális különbségek és a nemzetközi marketingmegfontolások mind az online média, mind a közösségi kereskedelem esetében releváns témakörök (Malota, 2011; Malota, 2015). Kína jelentősége az online média területén is óriási. A kínai nyelv a második leginkább használt nyelv lett a világon 2017-re 771 millió felhasználóval az angol nyelv mögött. Ez ténylegesen azt jelenti, hogy közel minden ötödik internetfelhasználó használja a kínai nyelvet, és ez „csupán” 54,1\%-os penetrációt jelent, így van még lehetőség a további terjeszkedésre (Internet World Stats, 2017). Másrészről, 2016 decemberében az internetpenetráció Kínában 53,2\% volt, 2,9 százalékkal magasabb 2015 év végéhez képest, ami 731 millió internethasználót jelent Kínában. A legtöbben közülük mobiltelefonon keresztül férnek hozzá az internethez. A mobilinternet-használók az összes internethasználó 95,1 százalékát jelentik, mint ahogy a mobilinternet-használók száma Kínában elérte a 695 millió föt (CNNIC, 2017). A viszonylagosan alacsonyabb penetrációs érték és az internethasználók számának növekedési trendje - különösen, ami a mobilinternet-használókat jelenti - azt mutatja, hogy még több kínai internethasználó lesz a jövőben, és arányuk a globális online médiafogyasztásban még jelentősebb lehet a jövőben, mivel Kína másik fele is valószínüleg internethozzáférést fog kapni.

Az internet helye a gazdaságban meglehetősen aktuális és fontos, mivel Kína internetes gazdasági tevékenysége új csúcspontot ért el 2017 második negyedévében, és 470,95 millió jüant tett ki, 19,3\%-os éves növekedést mutatva, amely érték magasabb, mint az adott évi GDP-növekedés (amely 11,1\% volt). Az online vásárlások éves növekedése 23,1\% volt, az online reklámozás növekedése 21,7\%. Egyrészt, a PC internetes gazdaság nyeresége több, mint 20\%ot csökkent, másrészt a mobilinternetes gazdaság elérte a 341,56 millió jüanos értéket, ami több, mint a teljes internetes gazdaság nyereségének 70\%-a. Egy gyors látlelet Kína internetes gazdaságára azt mutatja, hogy a nyereség 59,9\%a vásárlásból származik, 18,1\%-a reklámozásból, 12,6\%-a játékokból és 9,4\%-a fizetési szolgáltatásokból (iResearch, 2017). Így az okostelefonok és az integrált megoldások jelentősebbé válnak a gazdaságban, ahogy a mobilinternetes gazdaság egyre nagyobb, és az e-kereskedelem (vásárlás) az 
internetes gazdaság fö területévé vált Kínában. Az internetes gazdaság pedig meghatározó tényezőjévé vált a kínai gazdaságirányításnak, gazdaságpolitikának is, hiszen prioritásként megjelenik a 13. ötéves tervben is, amely a 2016-2020 közötti időszak prioritásait jelöli ki. A terv célja többek között az internetes gazdaság további kiterjesztése, az internet sebességének növelése, a díjak csökkentése, valamint az internettel kapcsolatos vállalkozások, üzleti megoldások, ellátási és logisztikai láncok innovációjának támogatása (Xinhua, 2015).

A legtöbb regisztrált felhasználóval rendelkező, legnépszerübb alkalmazások általában az internetes óriáscégekhez kapcsolódnak. A legnépszerübb alkalmazás Kínában jelenleg a Tencent, WeChat és a QQ, mint kommunikációs alkalmazások. A WeChat 960 millió, a QQ 626 millió felhasználóval rendelkezett. A harmadik legnépszerübb alkalmazás a Taobao, az Alibaba C2C (consumer-to-consumer) felülete, 619 milliós regisztrált felhasználóval 2017 decemberében. Emellett az Alibaba online és mobil pénzügyi fizetési alkalmazása, az Alipay volt az ötödik legnépszerübb alkalmazás, 598 millió felhasználóval. A Baidu online videófelülete, az iQiyi videós alkalmazás volt a negyedik legnépszerűbb 599 millió felhasználóval, amellett, hogy a Baidu „csak” a tizenegyedik legnépszerübb volt 414 millió felhasználóval (iResearch, 2018). Habár a regisztrált felhasználók száma valószínűleg eltér a tényleges felhasználók számától, az adatok mégis nyújtanak valamennyi információt, hogy megértsük az internetes felületek viszonylagos népszerüségét Kínában.

$\mathrm{Az}$ internetes óriáscégek platformjainak jelentőségét támasztja alá a China Internet Network Information Center (2017) nevü kínai kormányhivatal is. Az öt leggyakrabban használt alkalmazás is kötődik az integrált mobilalkalmazásokhoz. Az első a WeChat 79,6\%-kal, a második a QQ 60\%-kal, melyek egyben közösségimédia-felületek is. A harmadik a Taobao 24,1\%-kal, mint a fö e-kereskedelmi oldal, és az ötödik egy online fizetési alkalmazás, az Alipay 14,4\%-kal. A negyedik a mobil keresőmotor, a Baidu volt 15,3\%-kal (CNNIC, 2017). Így jelenleg a közösségi média, e-kereskedelmi és mobilfizetési felületek a leggyakrabban használt alkalmazások Kínában. Habár ez esetben az eredeti fö funkciót említettük a rangsorolásnál, a következő szakaszban célzottan mutatjuk be a közösségi média és e-kereskedelem funkciókkal rendelkező, felhasználók számára kialakított mobilfizetési lehetőségeket, valamint ezek integrálását egy alkalmazásba.

\section{Az online fizetési lehetőségekkel kibővített e-kereskedelmi és közösségimédia-funkciók integrált felületei}

A mobil és on-demand szolgáltatások (ahol a médiafogyasztók saját igény szerint kérhetik a tartalmakat, a nekik megfelelő időben; MEME, 2012) inspirálják a közösségi kereskedelem bizonyos formáit. A mobilfizetési megoldások beépülése az alkalmazásokba lényeges, hiszen így a felhasználók bankkártya nélkül férhetnek hozzá pénzügyi szolgáltatásokhoz. Mindezt a mobiltechnológia fejlödése tette lehetővé. A mobilfizetések általában szolgáltatásokhoz kapcsolódnak, általánosak és univerzálisak, és nem bankok vagy pénzügyi intézmények a szolgáltatók, tehát nem összekeverendő a mobilbankolással. Emellett a mobilfizetés iparági környezetére a kereskedelmi, technológiai, jogi és piaci tényezők jelentős hatással vannak (Iman, 2018). A mobilfizetés ráadásul növeli a vásárlási hajlandóságot is a készpénzes vásárláshoz képest, túl azon, hogy a mobilfizetés lehetősége kedvezőbb képet alakít ki a vásárlókban az egyes kereskedelemi egységek iránt (Falk et al., 2016).

Több, mint 600 millió ember van Kínában, akik rendelkeznek internetes hozzáféréssel a mobiltelefonjukról, akik az ország online lakosságának jelentős részét jelentik. Ezen felül, a széles körü mobil szélessávú hozzáférés öszsze van kapcsolva innovatív mobilfizetési rendszerekkel, amelyek függetlenek a hitelkártyáktól. Az Alibaba indította el a folyamatot a $\mathrm{C} 2 \mathrm{C}$ és $\mathrm{B} 2 \mathrm{C}$ Taobao és Tmall piacterekkel és az Alipay fizetési rendszerrel sok éve már, öszszekötve a vevői és eladói adatokat platformok, eszközök, fizetési és logisztikai csatornák között. A Tencent WeChat alkalmazása több, mint 700 millió felhasználóval sokoldalú mobilalkalmazás. Az alkalmazásba beépített QR-kód olvasó lehetővé teszi a felhasználók számára, hogy online és offline közegben is kapcsolódjanak a márkákhoz. A fizetés lehetővé tétele - összekötve a WeChat fiókot a bankfiókkal - lehetőséget teremt a felhasználóknak, hogy online és offline helyeken is, mindenütt és minden szolgáltatásért fizethessenek, a közmüszámláktól kezdve, a taxiszolgáltatáson át az éttermekig (ClickZ, 2016).

Az Alipay 2004 óta közeli együttmüködésben dolgozik több, mint 200 pénzügyi partnerrel azért, hogy fizetési szolgáltatásokat nyújtson több tízmillió kis- és középvállalat számára. Az Alipay több, mint 400 millió aktív egyéni felhasználóval rendelkezett 2015 júniusáig bezáróan. Amíg az Alipay online fizetési szolgáltatásokat tesz lehetővé, mindeközben igyekszik kiterjeszteni szolgáltatásait számos offline lehetőség felé is, hogy lefedje az éttermeket, szupermarketeket, kisboltokat, a taxiszolgáltatást és a tömegközlekedést is. A felhasználók több, mint 200.000 offline üzletnél és 500.000 taxinál fizethetnek az Alipay segítségével országszerte. Az Alipay globálissá válik úgy, hogy 30 ország és régió fogadja el az online és mobilfizetést. Több, mint 2.000 kereskedő írta alá, hogy elfogadja az Alipay használati feltételeit. Emellett az Alipay 14 különböző valutát fogad el. Mindemellett, később közösségimédia-tulajdonságokkal is bővítették az Alipay-t, amikor 2015 júliusában hozzákapcsolták a „barát”” gombot a szolgáltatáshoz, ahol a felhasználók kommunikálhatnak barátaikkal (Alipay, 2015).

A Baidu, Alibaba, Tencent és Sina együttesen nyolc különféle közösségimédia- és/vagy e-kereskedelmi felülettel rendelkeznek, mindegyik több száz millió aktív felhasználóval. Ezek a kínai közösségi és digitális látkép magját képezik, mivel összességében több, mint négymilliárd felhasználójuk van. A kínai közösségi média egyedülálló a fizetési rendszerek megoldásainak és az Alibaba Alibay és a Tencent Tenpay szolgáltatásainak mély integrációjában. A WeChat platform nem csupán e-kereskedelmi üzletkötésekhez alkalmas, de ezen kívül a személyközi (P2P: person to person) tranzakciókhoz is, számlafizetés- 
re, sőt, még befektetési alapokhoz kapcsolódó funkciók ellátásához is. Sehol máshol a világon nincs ilyen teljes körü közösségmédia-ökoszisztéma, amely ilyen észrevétlenül összeköti az internetes szájreklámot és a fizetési funkciókat. Most, ahogy a fizetés és a közösség média ennyire integrálttá válik, a közösségi média és az e-kereskedelem közötti határok egyre inkább elmosódnak. A hagyományos e-kereskedelmi oldalak magukba építenek közösségi funkciókat, és fordítva. A kínai internetes gazdasági látkép e tulajdonságai azt eredményezik, hogy ezek nem csupán egyedülálló felületek, amelyek sehol máshol nem léteznek, hanem egyben több, egymást átfedő platformok is, mint ahogy több egymást átfedő ökoszisztémák is, melyek mindegyike folyamatos átalakulásban van. Összehasonlítva a nyugati, kétplatformos stratégiával, amelyik a Facebookból és a Google-ból áll, a kínai közösségimédiakapcsolódású internet sokkal inkább egyedi, széttöredezett és dinamikus (Kantar Media, 2016).

Ennélfogva, a közösségi kereskedelem valósággá vált Kínában, a platformok azt mutatják, hogy a közösségi média és az e-kereskedelem közötti határok elmosódhatnak. Például a WeChat a mobil platformok megjelenésével fejlődött, és mostanra ez az egy alkalmazás a mobiltelefonban egy pénztárca, egy kommunikációs eszköz és egy csatorna is, amelyen lehet ételt, repülöjegyet, mozijegyet rendelni, leinteni (és fizetni) egy taxit, orvosi időpontot foglalni, közmüszámlákat befizetni, barátoknak pénzt utalni, fényképeket és képeket megosztani, és fizetni egy fizikai boltban az áruért úgy, hogy ugyanezt a telefont olvassuk be a pénztárnál. Felhasználva a beépített QR-kódot, alkalmazva a stratégiai tartalommarketing-stratégiát, és kihasználva a legtöbbet az új technológiákból és a háttérszoftverekből, a márkák számára lehetővé válik egy sor stratégiát alkalmazni, hogy bevonják a fogyasztókat mind az online, mind az offline terekbe Kínában (ClickZ, 2016). Így a Tencent WeChat mára nemcsak vezető közösségimédia-platform Kínában, hanem jelentős szerepe van az e-kereskedelmi és pénzügyi megoldások terén is. Mindamellett, az Alibaba nemcsak e-kereskedelmi felületet biztosít a felhasználók számára - mint a Taobao és a Tmall -, hanem ezen kívül bevon közösségimédia-funkciókat is, valamint fizetési megoldásokat kínál felhasználói számára. Jelenleg így történik az, hogy a közösségimédia-óriás és az e-kereskedelmi óriás egymás közvetlen versenytársaivá válnak a kínai internetes gazdaságban.

Kínában, a világ legnagyobb mobilfizetési szektorában a verseny meglehetősen kiélezett. Kína vezet a világon a mobilfizetések terén, amit elősegít az online vásárlások fellendülése, és az alternatív lehetőségek viszonylagos hiánya (mint amilyen a hitelkártya). A kínai mobilfizetés tavaly elérte az 5,5 trillió amerikai dollárt, ami az Egyesült Államok 112 milliárd dolláros piacának 50-szerese. Az Alibaba részesedése lecsökkent 71\%-ról (2015 harmadik negyedéve) 54\%-ra (2016 negyedik negyedéve), mialatt a Tencent elveszi a piacrészesedést az Alibabától, mivel az utóbbi 16\%-ról feljött 37\%-ra. Az ApplePay, amelyet 2016-ban vezettek be, nem volt képes bekerülni a 10 legjobb közé Kínában (Financial Times, 2017). 2015-röl 2016-ra a kínai mobilfizetés-felhasználók száma 30\%-kal növekedett. A 469 milliós felhasználói bázis a nemzet mobiltelefon-használóinak kétharmadát képviseli. Jelenleg az Alipay megközelítőleg 520 millió regisztrált felhasználóval rendelkezik, sokan közülük olyan e-kereskedelmi platformokat használnak, mint a Taobao. Az Alibaba piacrészesedése megközelítőleg 80\%-os volt 2014-ben. A Tenpay felülmúlja az Alipay-t a maga 600 milliós fizetési fiókjával. A WeChattel történő integráció felelős a felhasználói bázis éles fellendüléséért (ASEAN, 2017).

Összességében feltételezhetjük, hogy Kína vezető innovátor a globális mobilfizetési piacon. Az internetes gazdaság e területein megjelenő innovációk és új üzleti modellek rendelkeznek azzal a lehetőséggel, hogy elterjedjenek az egész világon, és átalakítsák az internetes gazdaság látképét a nyugati világban, beleértve Magyarországot is. Borsi (2017) szerint a globális innovációs rendszerek azokat a cégek által hozzáférhető erőforrásokat és intézményeket foglalják magukban, amelyek kiépülését és fejlődését sok-sok ország szervezeti interakciói alakítják. Valószínüleg, amit ma Kínában találunk, az lesz a jövő a világ más részein. Habár az is egy lehetőség, hogy sok innováció és új megoldás nem lesz globális siker, hanem Kína mobilinternetes gazdaságának speciális tulajdonsága marad. Mivel a Kínában működő internetes óriáscégek ösztönözve vannak a globalizálódásra, így fontos, hogy figyeljünk arra, hogy mi történik Kínában manapság. Emellett érdemes megjegyezni, hogy habár a technológia fejlődik, de a vállalatok számára is érdemes beépíteni a közös értékteremtésbe a vevőt, miközben folyamatosan érdemes fejleszteni képességeit, mert enélkül bármilyen kifinomult is egy közösségi mobilalkalmazás, ha a felhasználó nem képes tartani a lépést a technológiával (Kenesei - Kolos, 2018).

\section{Az internet és a közösségi mobilkereskedelem helyzete Magyarországon}

2016-ban a mobiltelefonos penetráció a magyar háztartásokban 92\%-os volt, lassú növekedési trend mentén. De a legfontosabb, hogy az okostelefonok penetrációja stabil növekvő trendet mutatott Magyarországon - elöször 2016ban - a háztartások többsége (52\%) rendelkezett okostelefonnal. Az internetpenetráció lassú növekedést mutat az országban, és a magyar háztartások 64\%-a rendelkezett vezeték nélküli internethozzáféréssel 2016 végére, habár a mobilinternet is gyors növekedést mutat, és a magyarok 40\%-a rendelkezett mobilinternet-elöfizetéssel ebben az évben (NMHH, 2017b). Így elmondható, hogy a technológiai háttér, a viszonylagosan magas okostelefon- és mobilinternet-penetráció megfelelő hátteréül szolgálhat az integrált közösségimédia- és e-kereskedelmi megoldásoknak.

Egy másik jelentés arról számol be, hogy az internethasználók közül 75\%-nak van a birtokában okostelefon, ami magasabb, mint a személyi számítógépek vagy laptopok aránya (58-58\%). Amíg az internethasználat a személyi számítógépeken csökken, az okostelefonok esetében fordított trend figyelhető meg. Ennélfogva a magyarok egyre aktívabb mobilinternet-használók, az internethasználók 64\%-a használta internetezésre az okostelefonját, mialatt $65 \%$ használt személyi számítógépet és 58\% laptopot 2016-ban, de amennyiben a trend folytatódik, úgy 
az okostelefon a legfontosabb internetes hozzáférést biztosító eszközzé válik. Hasonlóan Kínához, a leggyakrabban használt alkalmazások a közösségimédia-platformok, a magyarok 73\%-a használja a Facebookot, 64\%-uk pedig a Facebook Messengert okostelefonjaikon (NMHH, 2017a). Ez alapján, néhány internet- és mobilinternet-használatra vonatkozó jellemző mentén érdemes megvizsgálni a magyarok vélekedését a közösségimédia-jellemzőkkel bíró mobiltelefon-alkalmazásokról, hogy ezzel mintegy elöre jelezhetővé váljon, hogy a magyarországi felhasználók közösségimédia- és m-kereskedelmi használati jellemzői mennyiben térnek el adott esetben a kínai példától, valamint, milyen alapvető jellemzők mentén érdemes számolni a téma elméleti kutatóinak, illetve a gyakorlati szakembereknek.

\section{Mintajellemzők és módszertan}

Az adatgyüjtést online kérdöív formájában végeztük el. Mivel a téma online fogyasztói magatartást vizsgál magyar felhasználók körében, ezért a módszer megfelelőnek tűnt. A kutatásban igyekeztünk minimalizálni a megkérdezés és a megkérdezés tárgya közötti eltérésekből fakadó esetleges diszkrepanciát (Gyulavári et al., 2015). Emellett az online megkérdezés lehetővé tette a gyors és nagymintás mintavételt. A kérdőíves lekérdezés 2017. április 24-e és 2017. május 15-e között zajlott le, mivel azt feltételeztük, hogy ez a háromhetes időszak nagyszámú választ eredményezhetett, mindazonáltal a lehetséges torzítások az adatokban a viszonylag hosszú adatgyüjtési folyamat révén minimalizálódtak. Az adattisztítás után a következőkben bemutatandó modellek elemzése az adattisztítási fázis után a végleges mintaelemszámmal 844 válaszadó válasza alapján történt. Alapsokaságként a magyarországi mobiltelefon és közösségimédia-használó fogyasztókat határoztuk meg. Mivel önkéntes mintavételt folytattunk le, és mivel a válaszadók egyetemi hallgatók voltak - nagyrészt a Budapesti Corvinus Egyetemről, és kisebb részben a Károli Gáspár Református Egyetemről - ezért az eredmények nem tekinthetők reprezentatívnak. Ennek ellenére az eredmények valószínüsíthetően a témához kötődő, izgalmas és általános jellegű tendenciákra mutathatnak rá. Bár a kutatás kényelmi mintán alapult, de fontos feltétel volt a válaszadók mobiltelefon és közösségi média használata, amely így kiinduló alapot biztosított a vizsgált témakörhöz.

A minta $72 \%$-a nő, $28 \%$-a férfi. A nők magasabb aránya a hallgatói minta jellegzetességeinek köszönhető (a kutatásban részt vevő egyetemi szakok hallgatóinak nemi összetétele). A primer kutatás keretében a megkérdezettek átlagéletkora 23 év (szórás: 3,9 év), a leggyakoribb életkor érték (módusz) 22 év volt. A minta összetétele alapján megállapítható, hogy egyetemi hallgatókból állt a minta, akik feltételezhetően rendelkeznek okostelefonnal, és valószínüsíthetően nagy arányban szerepelnek a különféle közösségimédia-felületeken. A mintában szereplő válaszadók a mobiltelefonjukon jellemzően intenzíven használják a közösségi médiát (5,85-ös átlagérték a 7-fokozatú skálán, ahol a 7-es érték jelenti a legintenzívebb használatot), viszont a mobiltelefonjukon kevésbé jellemző a vásárlási tevékenység (2,79es átlagérték a 7-fokozatú skálán, ahol a 7-es érték jelenti a legintenzívebb vásárlási magatartást).

A kutatás során már tesztelt, nemzetközi modellekkel és skálákkal dolgoztunk, és azzal a céllal vizsgáltuk meg a nemzetközi modelleket, hogy a kutatás végén releváns következtetést mondhassunk a magyarországi mobil közösségimédia-kereskedelmi alkalmazásokkal kapcsolatosan. A használati hajlandóság elemzését Liebana-Cabanillas et al. (2017) modellje alapján vizsgáltuk, a vásárlási hajlandóság vizsgálatára Wang és Yu (2017) modelljét alkalmaztuk, majd a két modellt kombináltuk, és végül összehasonlító elemzést végeztünk rajtuk. Célunk volt, hogy megfigyeljük a két modell viselkedését a magyarországi mintán is, és meghatározzuk a fö eltéréseket, majd azok hatásait. Kutatási problémánk a vizsgált modellek müködésének tesztelése magyar közegben, kimutatva a vizsgált - használati és vásárlási hajlandósággal kapcsolatos - konstrukciók és öszszefüggéseik feltételezhetően megváltozott kapcsolatrendszerét és összefüggéseit, az eredeti modellben felvetett kutatási kérdések mentén. Célunk volt az is, hogy feltárjunk esetlegesen új összefüggéseket is, amelyek az eddig tesztelt modellek eredményeinek bemutatásakor nem kerültek elö.

A modellekben alkalmazott egyes változók mérhetővé tétele érdekében a nemzetközi kutatásokban tesztelt skálák adaptált változatait használtuk, amelyek jellemzőit az 1. táblázat tartalmazza.

A mért változók operacionalizálása

\begin{tabular}{|l|l|l|}
\hline \multicolumn{1}{|c|}{ Változó név } & \multicolumn{1}{|c|}{$\begin{array}{c}\text { Változó mérésére szolgáló skála } \\
\text { (7-fokozatú Likert-skála) }\end{array}$} & Forrás \\
\hline $\begin{array}{l}\text { Megfigyelt } \\
\text { fogyasztói } \\
\text { vásárlás }\end{array}$ & $\begin{array}{l}\text { Gyakran, amikor megvásárolnék egy márkát, akkor követném azokat } \\
\text { a felhasználókat, akik szintén megvásárolták ezt a terméket az oldalon. } \\
\text { Gyakran, amikor megvásárolnék egy márkát, akkor megfigyelném más } \\
\text { felhasználók korábbi vásárlásait az oldalon a vásárlási listáik és ellenőrző listáik } \\
\text { megtekintésével. } \\
\text { Gyakran, amikor megvásárolnék egy márkát, elolvasnám a korábbi hozzászóláso- } \\
\text { kat a termékröl. }\end{array}$ & $\begin{array}{l}\text { Wang - Yu } \\
(2017)\end{array}$ \\
\hline
\end{tabular}




\begin{tabular}{|c|c|c|}
\hline Pozitív szájreklám & $\begin{array}{l}\text { Ajánlanám a kedvenc mobil közösségimédia-kereskedelmi internetes oldalamat } \\
\text { másoknak. } \\
\text { Kedvezöen nyilatkoznék a kedvenc mobil közösségimédia-kereskedelmi internetes } \\
\text { oldalamról másoknak. } \\
\text { Kedvenc mobil közösségimédia-kereskedelmi internetes oldalam jó oldaláról be- } \\
\text { szélnék másoknak. } \\
\text { Büszkén beszélnék másoknak arról, hogy a kedvenc mobil közösségimédia-keres- } \\
\text { kedelmi internetes oldalam ügyfele vagyok. } \\
\text { Határozottan ajánlanám másoknak, hogy a kedvenc mobil közösségimédia-keres- } \\
\text { kedelmi internetes oldalamról vásároljanak termékeket online. } \\
\text { Többnyire pozitív dolgokat mondanék másoknak kedvenc mobil közösségimédia- } \\
\text { oldalamról. }\end{array}$ & $\begin{array}{l}\text { Goyette et al. } \\
(2010)\end{array}$ \\
\hline $\begin{array}{l}\text { Negatív szájrek- } \\
\text { lám }\end{array}$ & $\begin{array}{l}\text { Többnyire negatív dolgokat mondanék másoknak a kedvenc mobil közösségimédia- } \\
\text { kereskedelmi internetes oldalamon. } \\
\text { A kedvenc mobil közösségi kereskedelmi oldalam internetes kereskedőiről lebecs- } \\
\text { mérlően beszélnék másoknak. }\end{array}$ & $\begin{array}{l}\text { Goyette et al. } \\
(2010)\end{array}$ \\
\hline $\begin{array}{l}\text { A szájreklám } \\
\text { tartalma }\end{array}$ & $\begin{array}{l}\text { *A kínált termékek minőségét. } \\
\text { A kínált termékek változatosságát. } \\
\text { A felhasználóbarát jelleget. } \\
\text { A vásárlási tranzakciók biztonságosságát. } \\
\text { Az elérhető termékek árait. } \\
\text { A vásárlási tranzakciók egyszerüségét. } \\
\text { A kiszállítási módokat. } \\
\text { Az eladók megítélését. } \\
\text { * Mit gondolna, a kedvenc mobil közösségimédia-kereskedelmi oldalán mennyire } \\
\text { vitatná meg másokkal a következőket? }\end{array}$ & $\begin{array}{l}\text { Goyette et al. } \\
(2010)\end{array}$ \\
\hline Észlelt hasznosság & $\begin{array}{l}\text { A mobil közösségimédia-kereskedelem használata növelné a vásárlási feladatokban } \\
\text { nyújtott teljesítményem. } \\
\text { A mobil közösségimédia-kereskedelem használata növelné a vásárlási feladatok el- } \\
\text { végzésének eredményességét. } \\
\text { A mobil közösségimédia-kereskedelem használata fokozná a vásárlási feladatok el- } \\
\text { végzésének hatékonyságát. }\end{array}$ & $\begin{array}{l}\text { Chan - } \\
\text { Chong (2013) }\end{array}$ \\
\hline $\begin{array}{l}\text { A használat } \\
\text { észlelt könnyűsége }\end{array}$ & $\begin{array}{l}\text { A használatuk egyszerü lenne. } \\
\text { Az ilyen oldalak és applikációk világosak és érthetőek lennének. } \\
\text { A használatuk minimális erőfeszítést igényelne tőlem. } \\
\text { Könnyü lenne a használatuk megtanulása számomra. }\end{array}$ & $\begin{array}{l}\text { Chong et al. } \\
(2012)\end{array}$ \\
\hline Bizalom & $\begin{array}{l}\text { A vásárlási tranzakciók biztonságosak. } \\
\text { A felhasználók személyes adatai jól védettek. } \\
\text { A vásárlási tranzakciók megbízhatóak. } \\
\text { A biztonsági intézkedések megfelelőek. }\end{array}$ & $\begin{array}{l}\text { Chong et al. } \\
(2012)\end{array}$ \\
\hline Mobilitás & $\begin{array}{l}\text { A mobil közösségimédia-kereskedelmet bármikor lehetne használni. } \\
\text { A mobil közösségimédia-kereskedelmet bárhol lehetne használni. } \\
\text { A mobil közösségimédia-kereskedelmet utazás közben is lehetne használni. } \\
\text { A mobil közösségimédia-kereskedelemnek kényelmes lenne a használata, mivel a } \\
\text { mobiltelefonom majdnem mindig kéznél van. }\end{array}$ & $\begin{array}{l}\text { Kim et al. } \\
(2010)\end{array}$ \\
\hline $\begin{array}{l}\text { Személyre } \\
\text { szabhatóság }\end{array}$ & $\begin{array}{l}\text { Megítélésem szerint ezen oldalak, applikációk használata megfelel az igényeimnek. } \\
\text { A rendelkezésre álló információk és szolgáltatások összhangban vannak azzal, amit } \\
\text { előnyben részesítek. } \\
\text { A használatuk összhangban van a személyes normáimmal és értékeimmel. }\end{array}$ & $\begin{array}{l}\text { Yeh }-\mathrm{Li} \\
(2009)\end{array}$ \\
\hline $\begin{array}{l}\text { Használati } \\
\text { bevonódás }\end{array}$ & $\begin{array}{l}\text { Ha lenne egy hasznos ötletem arra vonatkozóan, hogy miként javíthatnám a mobil } \\
\text { közösségimédia-kereskedelmet, akkor ezt tudatnám a szolgáltatóval. } \\
\text { Amennyiben problémát tapasztalnék a mobil közösségimédia-kereskedelem hasz- } \\
\text { nálata közben, akkor ezt tudatnám a szolgáltatóval. } \\
\text { Szeretnék a részesévé válni a mobil kereskedelemben elérhető új termékek és szol- } \\
\text { gáltatások fejlesztésének. }\end{array}$ & $\begin{array}{l}\text { Yi-Gong } \\
(2013)\end{array}$ \\
\hline
\end{tabular}




\begin{tabular}{|l|l|l|}
\hline $\begin{array}{l}\text { Használati } \\
\text { hajlandóság }\end{array}$ & $\begin{array}{l}\text { Szándékomban áll a használatuk a közeli jövőben. } \\
\text { Úgy hiszem, hogy egyre inkább érdekelni fog a jövőben. } \\
\text { Mások számára is ajánlani fogom a használatukat. } \\
\text { Bátorítani fogom a barátaimat és családtagjaimat a használatukra. }\end{array}$ & $\begin{array}{l}\text { Zarmpou et al. } \\
(2012)\end{array}$ \\
\hline $\begin{array}{l}\text { Vásárlási } \\
\text { hajlandóság }\end{array}$ & $\begin{array}{l}\text { Valószínúleg megadnám a személyes adataimat a vásárláshoz. } \\
\text { Terveim szerint megadnám a személyes adataimat a vásárlásokhoz. } \\
\text { Szándékom szerint megadnám a személyes adataimat a vásárlásokhoz. } \\
\text { Szándékom szerint használnék mobil közösségi kereskedelmi oldalakat, hogy } \\
\text { megtaláljam az alacsonyabb árakat. }\end{array}$ & $\begin{array}{l}\text { Sharma - } \\
\text { Crossler } \\
(2014)\end{array}$ \\
\hline Vásárlás & $\begin{array}{l}\text { Vásárolt már valaha terméket a közösségi média segítségével korábban? } \\
\text { Vásárolt már valaha terméket mobil közösségi kereskedelmi oldalon korábban? }\end{array}$ & $\begin{array}{l}\text { Kim et al. } \\
(2008)\end{array}$ \\
\hline $\begin{array}{l}\text { Vásárlás utáni } \\
\text { tevékenységek }\end{array}$ & $\begin{array}{l}\text { Egy megrendelt termék átvétele után, osztott meg a termékkel kapcsolatban } \\
\text { információkat - mint termék értékelés, ajánlás, használati tapasztalat vagy panasz } \\
\text { - másokkal közösségi média alkalmazáson? } \\
\text { Egy megrendelt termék átvétele után, osztott meg a termékkel kapcsolatban } \\
\text { információkat - mint termék értékelés, ajánlás, használati tapasztalat vagy } \\
\text { panasz - másokkal mobil közösségimédia-kereskedelmi alkalmazáson? }\end{array}$ & et \\
(2008)
\end{tabular}

Forrás: Liebana-Cabanillas et al. (2017) és Wung és Yu (2017) alapján saját szerkesztés

\section{Elemzés, empirikus modellvizsgálatok}

Annak érdekében, hogy a válaszadók jobban megértsék az általunk vizsgálni szándékozott közösségi mobilkereskedelem fogalmát, az online kérdöívben alkalmaztunk olyan integrált mobilalkalmazásokra utaló kérdéseket, amelyek magukban hordozzák a közösségi média, a mobilkereskedelem és a mobilfizetési megoldások alkalmazását egyetlen applikációban. Néhány képet mutattunk a WeChat elnevezésű alkalmazásból, amelyet magyarázó szövegekkel is elláttunk annak érdekében, hogy a válaszadók minél inkább képesek legyenek elképzelni, hogyan müködik egy ilyen integrált alkalmazás, és miként kezelhetők benne a fő előnyeit jelentő egyes funkciók.

A modellekben az eredményeket a SmartPLS 2.0 (Ringle et al., 2005) szoftver segítségével kaptuk meg. A látens változók között a szakirodalom alapján 300 iteráció segítségével számítottuk ki a korrelációs együtthatókat. Az egyes kapcsolatok szignifikanciájának teszteléséhez az úgynevezett bootstrapping eljárást alkalmaztuk, ahol a modellek egyes változói esetében 200 véletlenszerüen generált almintával igyekeztünk kiszámítani a hibahatárokat (Chin, 2001). A PLS módszertanát alkalmaztuk a korábbi kutatások elméleti modelljeinek ismételt teszteléséhez a magyar minta felhasználásával, majd a további - származtatott - vizsgálódás során is. A PLS útelemzést azért választottuk, mert a nemzetközi összehasonlításon kívül a különféle konstrukciókat egységes modellben szerettük volna megjeleníteni. A módszer alapvetően képes összetett modelleket becsülni sok látens és manifeszt változó segítségével.

1. ábra

A használati hajlandóság befolyásoló tényezői

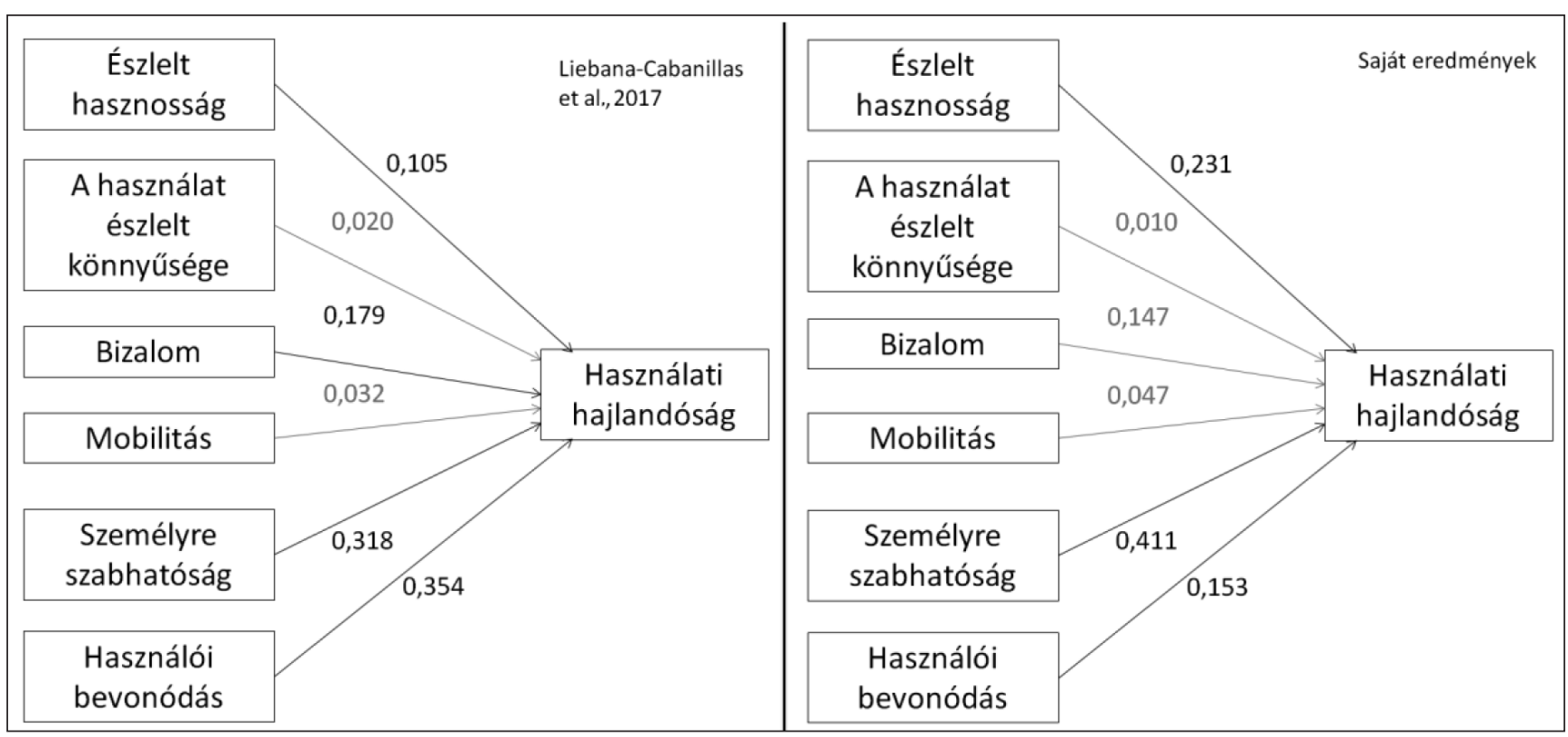

Forrás: Liebana-Cabanillas et al. (2017) alapján saját szerkesztés 
Illetve, mivel cél volt modellek kombinálása, így az elméleti fejlesztésben célunk volt tesztelni, validálni a feltáró modelleket, amelyekre a PLS lehetőséget biztosít (Henseler et al., 2009). Saját kutatásunkban két nemrégiben publikált kutatási modellt vizsgáltunk meg annak érdekében, hogy mélyebb betekintést nyerhessünk a magyar mobil felhasználók attitüdjeibe, vagyis, hogy vajon miként vélekedhetnek és hogyan fogadnák az úgynevezett mobil közösségi kereskedelemre alkalmas alkalmazásokat. A kutatás annak feltáró jellege miatt tehát elsősorban inkább a magyar kontextusban értelmezendő. Az első modell, amelyre támaszkodtunk, alapvetően az m-kereskedelem iránti elfogadást mérte. A Liebana-Cabanillas és munkatársai (2017) által közölt tanulmány Szerbiában készült, amelynek Magyarországhoz való viszonylagos közelsége jelentett számunkra kiindulási alapot kutatásunk tervezésekor, azt remélve, hogy az ott publikált modell felhasználásával mérhetővé tudjuk tenni az általunk megkérdezett magyar válaszadók elfogadását a mobilkereskedelem iránt, azzal a kiegészítéssel, hogy az általunk vizsgált kontextusban ez kiegészült a közösségi média és a mobilfizetés applikációban történő integrációjával. Ennek érdekében az eredeti kutatási kérdések minimális módosításával éltünk azért, hogy a mobil kereskedelem helyett a nem tudták megítélni, hogy mennyire lenne ez számukra megbízható alkalmazás. Az észlelt hasznosság, a személyre szabhatóság és a használók bevonódása bizonyult szignifikáns változóknak a mi kutatásunkban. Ennélfogva, mi elsősorban azzal a javaslattal tudunk élni, hogy a vizsgált több funkciót integráló alkalmazás esetében akkor várható használatuk, ha a felhasználók meggyőződhetnek hasznosságukról, és minél inkább saját felhasználási szokásaikhoz tudják igazítani ezeket.

A második modell a közösségi kereskedelem jelenségét vizsgálta, ezen belül is elsősorban ennek társas jellegét, amelyet empirikusan kutatásunkba adaptáltunk, és egyben az elméleti keretet is újrateszteltük a mobil közösségi kereskedelemre értelmezve abban a reményben, hogy mi is alaposabban megérthetjük a társas befolyás ráhatását a vásárlói magatartásban. Wang és Yu (2017) modelljét teszteltük a kutatásunkban, ahol a kiválasztás egyik indoka volt, hogy az eredeti modell Taiwanban készült, tehát kínai kulturális háttér mellett, ahol az úgynevezett mobil közösségi kereskedelem kategóriájába sorolható applikációk jelentős népszerüségre tettek szert. Ugyanakkor az eredeti kérdéseket némileg itt is módosítottuk, hogy a közösségi kereskedelem helyett a mobil közösségi kereskedelem kerüljön a vizsgálódás fókuszába (2. ábra).

2. ábra

A vásárlási hajlandóság befolyásoló tényezői és hatása a vásárlásra

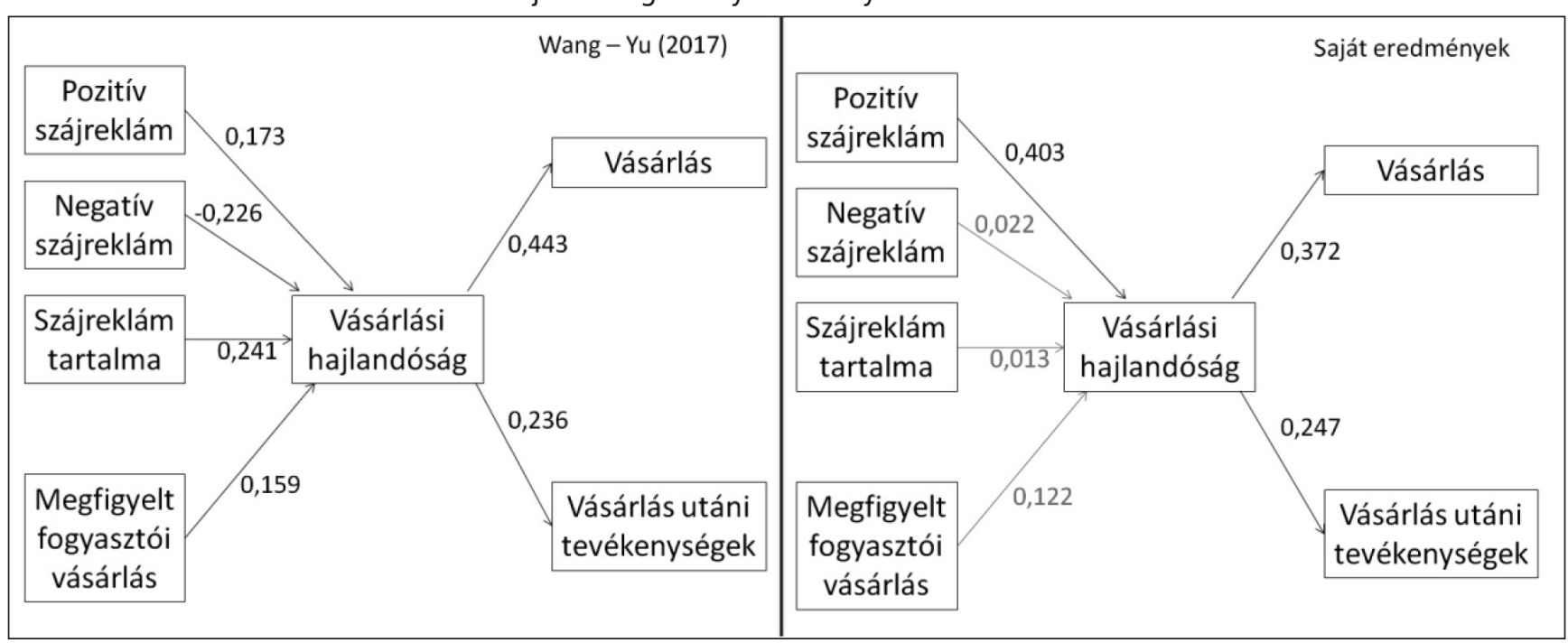

Forrás: Wung és Yu (2017) alapján saját szerkesztés

mobil közösségi kereskedelem legyen vizsgálatunk fókusza (1. ábra).

Az eredmények több hasonlóságot is mutattak a szerbiai eredményekkel, mert a használat észlelt könnyűsége és a mobilitás nem bizonyult szignifikáns tényezőnek az általunk végzett kutatás során sem. Ugyanakkor azt hangsúlyoznunk kell, hogy az általunk vizsgált kutatásban a bizalom szintén nem bizonyult szignifikáns tényezőnek, azaz, hogy miért lenne hajlandó egy válaszadó a mobil közösségi kereskedelem lehetőségét biztosító applikációk használatára. Ennek oka talán az előzetes személyes tapasztalat hiányában kereshető, ami nyomán válaszadóink
Ebben az esetben több jelentős különbséggel szembesültünk az adatok elemzésekor az eredeti modell által leírt várható összefüggések vizsgálatakor. Az általunk megkérdezett magyar felhasználók között az egyetlen tényező, amely képes volt szignifikáns hatást gyakorolni a várható vásárlási hajlandóságra, az a pozitív társas befolyásból eredt (pozitív szájreklám). Ez alapján az esetleges, támogató ajánlások elősegíthetik a mobil közösségi kereskedelmi funkcióval rendelkező alkalmazások elterjedését, de ezzel szemben a negatív szájreklám, sőt maga a szájreklámban található tartalmi elemek hatása nem bizonyult szignifikánsnak. Mivel ezen alkalmazások jelenleg nem 
széles körben ismertek és léteznek Magyarországon, ezért az esetlegesen ezzel kapcsolatban megfigyelt fogyasztói vásárlások hatására kevéssé számítottunk, és ez a tényező ennek megfelelően nem is bizonyult szignifikánsnak $\mathrm{Az}$ adaptált modell további elemei többé kevésbé követték az alapul vett modell által feltárt összefüggéseket, miszerint a vásárlási hajlandóság valamivel nagyobb hatást gyakorolt az esetleges vásárlásra és valamivel kisebb hatást a vásárlási utáni tevékenységekre, és mindkét ilyen hatás szignifikánsnak bizonyult.

A modellezés harmadik szakaszában megkíséreltünk egyfajta kombinált modellt felállítani az előző két modell változóinak felhasználásával. A célunk az volt, hogy egy komplexebb modell segítségével jobb betekintést nyerjünk a mobil közösségi kereskedelem elfogadásával és használatával kapcsolatos attitűdökbe, nevezetesen, hogy miként fogadnának válaszadóink egy olyan mobil applikációt, amely ötvözi a közösségi kereskedelem, mobilkereskedelem és mobilfizetés lehetőségeit. A kombinált modell alkalmazásával abban bíztunk, hogy feltárhatjuk a Kínában már müködő rendszer lehetséges fogadtatását hazánkban. A modellek egyes elemeit iterálva törekedtünk arra, hogy - a SmartPLS által talált szignifikáns kapcsolatokra alapozva - egy minél több változót tartalmazó modellt felépítve teszteljük a változók egymás közötti hatásainak meglétét, erősségét és irányát is (3. ábra). következtethetünk, hogyha sikerül megnyerni a fogyasztókat egy ilyen applikáció használatára, akkor várhatóan ezen az alkalmazáson idővel vásárlási és fizetési tranzakciókat is lebonyolítanának. A fogyasztók megnyeréséhez vezető út pedig a vizsgált változók egy részén keresztül, az észlelt hasznosság - vagyis annak mértéke, hogy a fogyasztók valóban érezzék a különféle mobil közösségimédia-kereskedelmi applikációk tényleges hasznát számukra - szignifikáns befolyásoló tényezőnek bizonyult. Az egyes alkalmazások egyedi jellege, személyre szabható formája szintén fontos tényezőnek bizonyult az eredmények alapján, tehát amennyiben van lehetőség a fogyasztó egyedi információigényéhez és értékrendjéhez kötni egy alkalmazást, úgy valószínübb, hogy a fogyasztó használni fogja azt, majd vásárolni fog az adott platformon. A használati bevonódás is szignifikáns kapcsolatot mutatott a használati hajlandósággal, vásárlási hajlandósággal, majd pedig a vásárlással és vásárlás utáni tevékenységekkel oly módon, hogy amennyiben a fogyasztó érzi annak lehetőségét, hogy ő maga javíthatja az egyes alkalmazások által nyújtott szolgáltatások színvonalát, úgy valószínübb a bevonódás révén a használat és a vásárlás is.

A modellek kombinálása során ugyan a bizalom beépíthetőnek bizonyult a vásárlási hajlandóság közvetlen indikátoraként, mint szignifikáns változó, ugyanakkor ebben az esetben a szájreklám szerepe elveszett, és a társas befolyás

A használati és vásárlási hajlandóság kombinált modellje

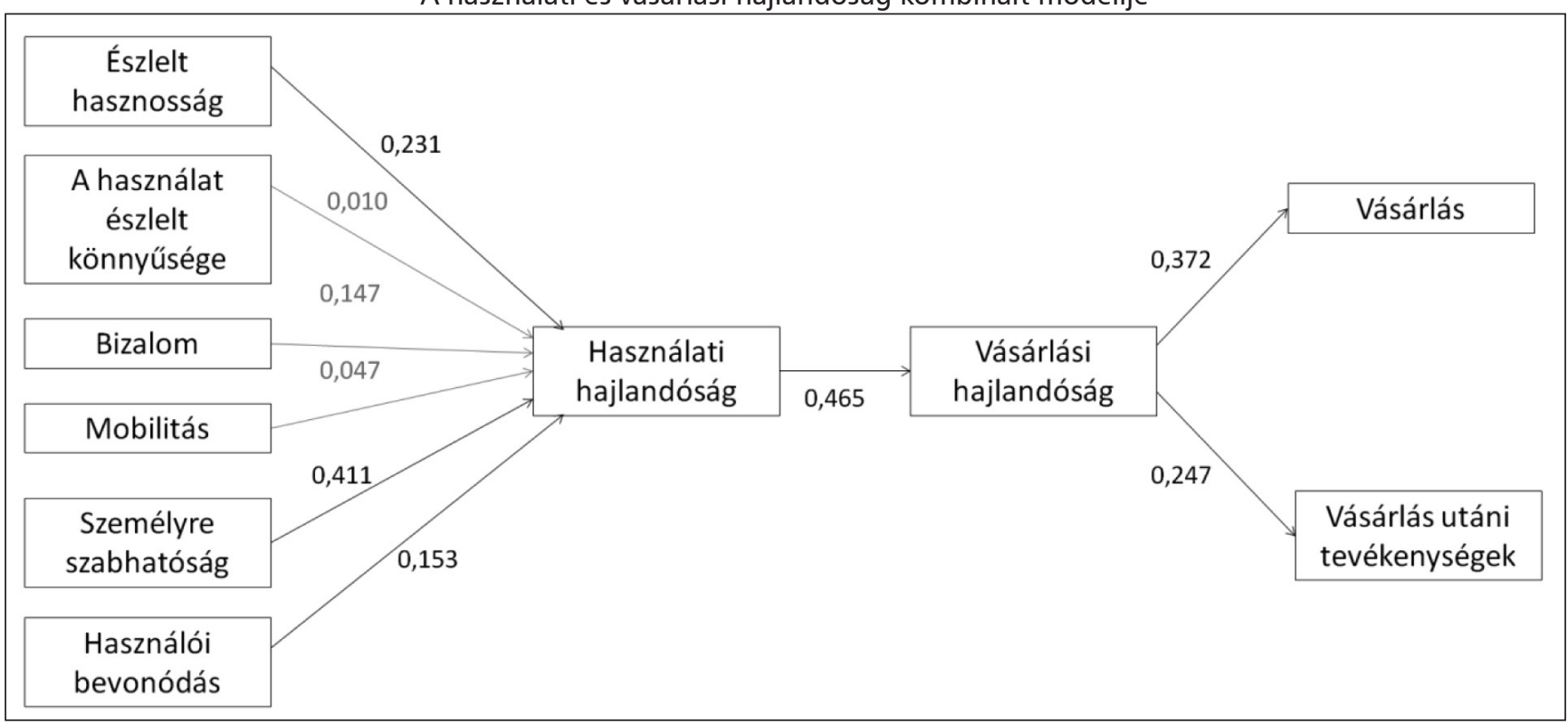

Forrás: Liebana-Cabanillas et al. (2017) és Wung és Yu (2017) alapján saját szerkesztés

Az egyik ezek közül az iterált modellek közül arra engedett következtetni, hogy felírható egy kapcsolati háló az applikáció elfogadását jelentő tényezőktől egészen a vásárlásig. A szignifikáns kapcsolat alapján az észlelt hasznosság, a személyre szabhatóság és a használói bevonódás elősegíthetik a használati hajlandóságot, amely utána hozzájárulhat a vásárlási hajlandósághoz egy ilyen applikáció esetében, amely végül hozzájárul a vásárláshoz, illetve később, a vásárlási utáni tevékenységekhez. Ez alapján arra szerepe így kiszorult a vásárlási hajlandóságot magyarázó tényezők közül. Meglehet, mivel a megkérdezetteknek nem rendelkeztek előzetes személyes tapasztalatokkal a vizsgált applikációs megoldások terén, így nem is voltak képesek érdemben elképzelni, hogy egy ilyen applikáció esetében a társas befolyás miként müködne. Noha e mobil applikációk esetében a közösségi média - és így a társas befolyás - feltételezésünk szerint lényeges tényezőként lenne jelen a rendszerhez való csatlakozás vagy a használat során. 


\section{Menedzseri ajánlások és összegzés}

Eredményeink gyakorlati értelemben is hasznosak lehetnek azon szervezetek számára, amelyek a mobiltelefonon keresztül alkalmazott, közösségimédia-elemekkel kiegészített e-kereskedelmi megoldásokkal élnének a fogyasztók felé. A magyarországi fogyasztók kezdeti fázisában vannak jelenleg az m-kereskedelem elfogadásának, így esetükben az oktatás és képzés elsődleges, mielőtt bármilyen kifinomult technológia bevezetésére kerülne sor. Ami jelenleg Kínában a valóság, az Magyarországon a lehetséges jövő, így érdemes lenne sok megoldási elvet megfelelő tudatossággal, igény esetén átalakítva tesztelni. Ezzel egy, már máshol valamilyen formában bevált rendszert lehetne mintegy „elötesztelve” itthon is alkalmazni a vállalatok számára. Az eredmények így arra engednek következtetni, hogy a potenciális felhasználók oktatása elengedhetetlen lenne a bevezetés előtt, mivel az alkalmazás, és különösen a vásárlás a közösségi mobil kereskedelmi applikációk segítségével máskülönben komoly kihívásokkal nézne szembe. Elsőként az ismerethiányból és így a képzelet korlátosságából adódó korlátokat lenne szükséges lebontani a fogyasztók fejében, hogy aztán a személyes előnyökért cserébe rávehetők legyenek az alkalmazások telepítésére és használatára. Ehhez kapcsolódóan, a magyar piacra belépő vállalatoknak mindenekelött a személyes elönyökre érdemes építeni a potenciális fogyasztók meggyőzését, és meg kell próbálni bevonni őket a használatba, ezáltal pedig hangsúlyozni kell a lehetséges személyre szabhatóságot. A személyes előnyök miatt a legvalószínübb, hogy rávehetők az applikációk használatára a megkérdezettek.

A kutatás korlátai között szerepel, hogy az alkalmazott hallgatói minta nem reprezentatív, így az eredményeik is csupán korlátok között általánosíthatóak. Az így kapott eredmények leginkább általános jellegzetességeket tártak fel. A nemzetközi és a magyar minta közötti összefüggések vizsgálata azt mutatja, hogy más nemzeteknél esetleg egyéb eltérések is kimutathatók lettek volna, mely részben korlát, részben jövőbeni lehetőség is a kutatást tekintve. A technológia és a vizsgált m-kereskedelmi, valamint közösségimédia-innovációk akár 1-2 év távlatából is elavulttá tehetik a kutatási eredmények egy részét. Új platformok megjelenése megváltoztathatja a felvázolt piaci helyzetet és jelenleg rögzült állapotokat, amelyek a turbulens közeg révén akár hónapról hónapra átírhatják a vizsgált piac jellegzetességeit.

A kutatás jövőbeli lehetőségeinek egyike, hogy többszöri keresztmetszeti kutatás révén megvizsgáljuk a használati és vásárlási hajlandóság befolyásoló tényezőinek hatásait, illetve e tényezők változásait. Érdekes kérdés lehet pár év távlatából megvizsgálni, hogy a jelenleg leginkább Kínában elterjedt integrált platformok mennyire honosulnak meg hazánkban is, hiszen akkor lehet valódi összehasonlító elemzést végezni nemzetközi kontextusban, akár addigra már közössé váló platformokon végezve el az elemzést. A jövőben más módszertan segítségével, tartalomelemzéssel lehetne vizsgálni a tényleges vásárlási hajlandóság és vásárlási tevékenység elemzését közösségimédia-felületeken végzett megfigyelési módszertan segítségével.

\section{Felhasznált irodalom}

Alalwan, A. A. - Rana, N. P. - Dwivedi, Y. K. - Algharabat, $R$. (2017): Social Media in Marketing: A Review and Analysis of the Existing Literature. Telematics and Informatics, 34(7), p.1177-1190.

Alibaba (2015): 支付宝简介 (Introduction of Alipay), https://ab.alipay.com/i/jieshao.htm (Letöltés ideje: 2018.06.02)

ASEAN Today (2017): Alipay and Tenpay compete headto-head for overseas market share. Letöltve: https:// www.aseantoday.com/2017/09/alipay-and-tenpaycompete-head-to-head-for-overseas-market-share/ (2017.09.30)

Ashraf, A. R. - Thongpapanl, N. - Menguc, B. - Northey, $G$. (2017): The role of $\mathrm{m}$-commerce readiness in emerging and developed markets. Journal of International Marketing, 25(2), p. 25-51. DOI https://doi.org/10.1509/ jim.16.0033

Balasubramanian, S. - Peterson, R.A. - Jarvenpaa, S.L. (2002): Exploring the Implications of M-Commerce for Markets and Marketing. Journal of the Academy of Marketing Science, 30(4), p. 348-361. DOI https://doi. org/10.1177/009207002236910

Berdykulova, G. M. K. - Sailov, A. I. U. - Kaliazhdarova, S. Y. K. - Berdykulov, E. B. U. (2014): The Emerging Digital Economy: Case of Kazakhstan. Procedia - Social and Behavioral Sciences, 109, p. 1287-1291.

Borsi B. (2017): Vállalatok az innovációs rendszerben. Vezetéstudomány / Budapest Management Review, 48 (6-7). p. 20-26. DOI https://doi.org/10.14267/VEZTUD.2017.06.03

Bronnenberg, B. J. - Ellickson, P. B. (2015): Adolescence and the path to maturity in global retail. Journal of Economic Perspectives, 29(4), p. 113-134. DOI https:// doi.org/10.1257/jep.29.4.113

CNNIC (2017): Statistical Report on Internet Development in China (January 2017). Letöltve: http:// cnnic.com.cn/IDR/ReportDownloads/201706/ P020170608523740585924.pdf (2017.06.08)

Chan, F. T. - Yee-Loong Chong, A. (2013): Analysis of the determinants of consumers'm-commerce usage activities. Online Information Review, 37(3), p. 443-461. DOI https://doi.org/10.1108/OIR-01-2012-0012

Chang, S. C. - Sun, C. C. - Pan, L. Y. - Wang, M. Y. (2015): An Extended TAM to Explore Behavioural Intention of Consumers to Use M-Commerce. Journal of Information \& Knowledge Management, 14(2) DOI https:// doi.org/10.1142/S0219649215500148

Chin, W. W. (2001): PLS-graph user's guide, version 3.0. Soft Modeling Inc., Houston

Chong, A. Y. L. - Chan, F. T. - Ooi, K. B. (2012): Predicting consumer decisions to adopt mobile commerce: Cross country empirical examination between China and Malaysia. Decision Support Systems, 53(1), p. 3443. DOI https://doi.org/10.1016/j.dss.2011.12.001

ClickZ (2016): Five reasons why China is a role model for digital innovation. https://www.clickz.com/five-reasons-why-china-is-a-role-model-for-digital-innovation/103591 (2016.07.21) 
Csordás T. - Markos-Kujbus É. - Gáti M. (2014): The Attributes of Social Media as a Strategic Marketing Communications Tool. Journalism and Mass Communication, 4(1), p. 48-71.

Davis, F. D. - Bagozzi, R. P. - Warshaw, P. R. (1989): User acceptance of computer technology: a comparison of two theoretical models. Management science, 35(8), p. 9821003.

Eastin, M. S. - Brinson, N. H. - Doorey, A. - Wilcox, G. (2016): Living in a big data world: Predicting mobile commerce activity through privacy concerns. Computers in Human Behavior, 58, p. 214-220.

Falk, T. - Kunz, W. H. - Schepers, J. - Mrozek, A. J. (2016): How mobile payment influences the overall store price image. Journal of Business Research, 69(7), p. 24172423.

Filo, K. - Lock, D. - Karg, A. (2015): Sport and social media research: A review. Sport Management Review, 18(2), p. 166-181. DOI https://doi.org/10.1016/j.smr.2014.11.001

Financial Times (2017): Race for China's \$5.5tn mobile payment market hots up. Letöltve: https://www. ft.com/content/e3477778-2969-11e7-bc4b-5528796fe35c (2017.05.01)

Füzes P. - Gódor Z. - Szabó Zs. R. (2018): Szabadulás a kiaknázási csapdából a digitális jövő alakításával. Hogyan irányítható az iparági változás egy felhőalapú szolgáltatásra épülő kiaknázási és felderítési tevékenységgel? Vezetéstudomány / Budapest Management Review, 49(1). p. 54-64. DOI https://doi.org/10.14267/VEZTUD.2018.01.06

Ghose, A. - Li, B. - Liu, S. (2016): Mobile targeting using customer trajectory patterns. Elérhető SSRN: https://ssrn. com/abstract=2962044 or DOI http://dx.doi.org/10.2139/ ssrn. 2962044

Goyette, I. - Ricard, L. - Bergeron, J. - Marticotte, F. (2010): eWOM Scale: word of mouth measurement scale for eservices context. Canadian Journal of Administrative Sciences/Revue Canadienne des Sciences de l'Administration, 27(1), p. 5-23. DOI https://doi. org/10.1002/cjas.129

Gyulavári T. - Mitev A. Z. - Neulinger Á. - Neumann-Bódi E. - Simon J. - Szücs K. (2015): A marketingkutatás alapjai. Budapest: Akadémiai Kiadó

Hasnaoui, A. - Freeman, I. (2010): Diffusion and implementation of corporate social responsibility (csr): the role of information and communication technologies (ict). Management \& Avenir, (9), p. 386-406.

Henseler, J. - Ringle, C. M-Sinkovics, R. R. (2009): The use of partial least squares path modeling in international marketing. In: Sinkovics, R. R - Ghauri, Pe. N. (ed.) New Challenges to International Marketing. Advances in International Marketing, Vol. 20, Emerald Group Publishing Limited, p. 277-319.

Hew, J.-J. - Lee, V. H. - Ooi, K.-B. - Lin, B. (2016): Mobile social commerce: The booster for brand loyalty? Computers in Human Behavior, 59, p. 142-154.

Horváth D. - Nyírö N. - Csordás T. (2013): Médiaismeret. Reklámeszközök és reklámhordozók. Budapest: Akadémiai Kiadó
Iman, Nofie (2018): Is mobile payment still relevant in the fintech era? Electronic Commerce Research and Applications, 30, p. 72-82.

iResearch (2017): The Revenue of China's Internet Economy Reached a New Height in Q2 2017. Letöltve: http:// www.iresearchchina.com/content/details7_37796.html (2017.10.16)

iResearch (2018): Top 500 Apps in China by UDs in December 2017. Letöltve: http://www.iresearchchina.com/ content/details7_40867.html (2018.02.05)

Kantar Media (2016): The State of Chinese Social Media in 2016. http://www.cicdata.com/index.php?option=com content $\&$ view $=$ article $\&$ id $=1338 \% 3$ A2016\&catid $=104 \%$ 3Aarchives-2016\&Itemid=213\&lang=en (Letöltés ideje: 10.08.2016)

Kenesei Zs. - Kolos K. (2018): Szolgáltatásmarketing: múlt vagy jövő? Vezetéstudomány / Budapest Management Review, 49(1). p. 2-12. DOI https://doi.org/10.14267/ VEZTUD.2018.01.01

Keszey T. - Zsukk J. (2017): Az új technológiák fogyasztói elfogadása. A magyar és nemzetközi szakirodalom áttekintése és kritikai értékelése. Vezetéstudomány / Budapest Management Review 48(10). p. 38-47. DOI https:// doi.org/10.14267/VEZTUD.2017.10.05

Kim, D. J. - Ferrin, D. L. - Rao, H. R. (2008): A trust-based consumer decision-making model in electronic commerce: The role of trust, perceived risk, and their antecedents. Decision Support Systems, 44(2), p. 544-564. DOI https://doi.org/10.1016/j.dss.2007.07.001

Kim, C. - Mirusmonov, M. - Lee, I. (2010): An empirical examination of factors influencing the intention to use mobile payment. Computers in Human Behavior, 26(3), p. 310-322. DOI https://doi.org/10.1016/j.chb.2009.10.013

Kotler, P. - Keller, K. L. (2012): Marketing Management. New York: Prentice Hall, p. 438-441.

Kourouthanassis, P. E. - Giaglis, G. M. (2012): Introduction to the special issue mobile commerce: the past, present, and future of mobile commerce research. International Journal of Electronic Commerce, 16(4), p. 5-18. DOI https://doi.org/10.2753/JEC1086-4415160401

Liébana-Cabanillas, F. - Marinković, V. - Kalinić, Z. (2017): A SEM-neural network approach for predicting antecedents of m-commerce acceptance. International Journal of Information Management, 37(2), p. 14-24. DOI https:// doi.org/10.1016/j.ijinfomgt.2016.10.008

Malota E. (2011): Kultúrák és kommunikáció [Cultures and communication], Esettanulmányok és gyakorlatok. Budapest: Budapesti Corvinus Egyetem

Malota E. (2015): Marketing nemzetközi színtéren: Esettanulmányok a hazai és külföldi piacokról. Budapest: Alinea Kiadó

MEME (2012): A lekérhető médiaszolgáltatások piaca Magyarországon és a piaci trendek várható alakulása. Magyar Elektronikus Müsorszolgáltatók Egyesülete (MEME). Letöltve: http://mediatorveny.hu/dokumentum/551/Meme_Ondemand_Deskresearch.pdf (2012.11.28)

Narang, U. - Shankar, V. (2016): The effects of mobile apps on shopper purchases and product returns. Mays Busi- 
ness School Research Paper No. 2878903. Available at SSRN: https://ssrn.com/abstract=2878903 or DOI http:// dx.doi.org/10.2139/ssrn.2878903

NMHH (2017a): Lakossági Internethasználat. Online piackutatás 2016. (Internet usage by individuals. Online survey 2016). Letöltve: http://nmhh.hu/dokumentum/187704/lakossagi_internethasznalat_2016.pdf (2017.05.02)

NMHH (2017b): Távközlési szolgáltatások használata a lakossági felhasználók körében 2016. (Electronic Communication Services Usage by Households and Individuals 2016). Letöltve: http://nmhh.hu/dokumentum/173422/lakossagi_tavkozles_2016_teljes_vegleges. pdf (2017.03.09)

Reddick, C. G. (2009): Handbook of Research on Strategies for Local E-Government Adoption and Implementation: Comparative Studies (2 Volumes). IGI Global. DOI 10.4018/978-1-60566-282-4

Ringle, C. M. - Wende, S. - Will, S. (2005): SmartPLS 2.0 (M3) Beta, Hamburg 2005. Letöltve: http://www.smartpls.de

Sharma, S. - Crossler, R. E. (2014): Disclosing too much? Situational factors affecting information disclosure in social commerce environment. Electronic Commerce Research and Applications, 13(5), p. 305-319. DOI https://doi.org/10.1016/j.elerap.2014.06.007

Sheth, J. N. - Mittal, B. - Newman, B. I. - Sheth, J. N. (2004): Customer behavior: A managerial perspective. Boston: Thomson/South-Western
Tóth-Kaszás N. (2017): A marketingkommunikációs mix. In: Lőrincz K. - Sulyok J. (2017): Turizmusmarketing. Budapest: Akadémiai Kiadó

Wang, Y. - Yu, C. (2017): Social interaction-based consumer decision-making model in social commerce: The role of word of mouth and observational learning. International Journal of Information Management, 37(3), p. 179-189. DOI https://doi.org/10.1016/j.ijinfomgt.2015.11.005

Xinhua (2015): Highlights of proposals for China's 13th FiveYear Plan. Letöltve: http://news.xinhuanet.com/english/ photo/2015-11/04/c_134783513.htm (2015.11.04)

Yan, Q. - Wu, S. - Wang, L. - Wu, P. - Chen, H. - Wei, G. (2016): E-WOM from e-commerce websites and social media: Which will consumers adopt? Electronic Commerce Research and Applications, 17, 62-73. DOI https:// doi.org/10.1016/j.elerap.2016.03.004

Yeh, S. Y. - Li, Y. M. (2009): Building trust in m-commerce: contributions from quality and satisfaction. Online Information Review, 33(6), p. 1066-1086. DOI https://doi. org/10.1108/14684520911011016

Yi, Y. - Gong, T. (2013): Customer value co-creation behavior: Scale development and validation. Journal of Business Research, 66(9), 1279-1284. DOI https://doi. org/10.1016/j.jbusres.2012.02.026

Zarmpou, T. - Saprikis, V. - Markos, A. - Vlachopoulou, M. (2012): Modeling users' acceptance of mobile services. Electronic Commerce Research, 12(2), p. 225-248. DOI https://doi.org/10.1007/s10660-012-9092-X 